\title{
The general methodological approach to development of modern foam washing agents
}

As the results of the analysis of the modern Ukrainian market for personal care products show, there is a clear tendency of the increased consumer interest, in particular to detergent-based liquid hygiene products.

Aim. To develop a methodological unified approach for creation of foaming agents in two $\mathrm{pH}$ intervals of 3.5-4.5 and 5.0-6.0.

Materials and methods. The methodological basis of this research is general scientific and applied methods of research, including methods of logical, historical, physicochemical, technological and analytical analysis. The modern Ukrainian market of foam washing agents and various types of detergents for obtaining satisfactory consumer properties were analyzed.

Results and discussion. A wide production range of foam washing agents of the foreign and domestic origin has been analyzed, and the active functional groups, as well as excipients and biologically active substances have been systematized. The conceptual differences in the approaches to development of parapharmaceutical cleansing agents and the tendency to use modern surfactants with the "soft" action have been revealed. It has been found that creation of uniform foaming agents in two $\mathrm{pH}$ intervals of 3.5-4.05 and 5.0-6.0 when applied to sensitive areas of the skin and mucous membranes determines the selection of detergents that would combine sufficient functional properties and dermatological characteristics. The analysis has shown that there is a need to develop new approaches to the use of multifunctional complexes of modern detergents.

Conclusions. A methodological unified approach for creation of foam washing agents in two $\mathrm{pH}$ intervals of 3.5-4.05 and 5.0-6.0 has been offered. It allows facilitating development of products and their introduction into domestic production.

Key words: cleansing foam washing agents; detergents; $p H$; shampoos; gels; personal hygiene products

\section{І. І. Баранова, Л. С. Петровська, Ю. О. Безпала, С. В. Заїка}

\section{Загальний методологічний підхід до розробки сучасних піномийних засобів}

Як свідчать результати аналізу сучасного українського ринку засобів по догляду за особистою гігієною, на теперішній час спостерігається чітка тенденція до зростання споживчого інтересу, зокрема до рідких гігієнічних засобів на основі детергентів.

Мета роботи - розробка методологічного уніфікованого підходу до створення піномийних засобів у двох інтервалах $\mathrm{pH}(3,5-4,5)$ та $(5,0-6,0)$.

Матеріали та методи. Методологічною основою даного дослідження є загальнонаукові та прикладні наукові методи дослідження, в тому числі методи логічного, історичного, фрізико-хімічного, технологічного та аналітичного аналізу. Проаналізований сучасний український ринок піномийних засобів та різні типи детергентів для отримання задовільних споживчих властивостей.

Результати та їх обговорення. Проаналізовано широкий асортиментний ряд піномийних засобів закордонного та вітчизняного виробництва та систематизовані активні функціональні групи, допоміжні та біологічно активні речовини. Виявлені концептуальні відмінності у підходах до розробки парафармацевтичних засобів очищувальної дії та тенденцію до використання сучасних поверхнево-активних речовин «м'якої» дії. Встановлено, що створення уніфікованих піномийних засобів у двох інтервалах $\mathrm{pH}(3,5-4,5)$ та $(5,0-6,0)$ при нанесенні на чутливі ділянки шкіри та слизові оболонки зумовлює вибір детергентів, які б поєднували достатні фрункціональні властивості та дерматологічні характеристики. Проведений аналіз показав, що є потреба у розробці нових підходів до використання багатофункціональних комплексів сучасних детергентів.

Висновки. Запропоновано методологічний уніфікований підхід щодо створення піномийних засобів у двох інтервалах $\mathrm{pH}(3,5-4,05)$ та $(5,0-6,0)$, що вперше дозволить полегшити розробку засобів та їх впровадження у вітчизняне виробництво.

Ключові слова: піномийні засоби очищувальної дї; детергенти; рH; шампуні; гелі; засоби особистої гігієни

\section{И. И. Баранова, Л. С. Петровская, Ю. А. Беспалая, С. В. Заика}

\section{Общий методологический подход к разработке современных пеномоющих средств}

Как свидетельствуют результаты анализа современного украинского рынка средств по уходу за личной гигиеной, сегодня наблюдается четкая тенденция роста потребительского интереса, в частности, к жидким гигиеническим средствам на основе детергентов.

Цель работы - разработка методологического унифицированного подхода к созданию пеномоющих средств в двух интервалах $\mathrm{pH}(3,5-4,5)$ и $(5,0-6,0)$. 
Материалы и методы. Методологической основой данного исследования являются общенаучные и прикладные научные методы исследования, в том числе: методы логического, исторического, физико-химического, технологического и аналитического анализа. Был проанализирован современный украинский рынок пеномоющих средств и различные типы детергентов для получения удовлетворительных потребительских свойств.

Результаты и их обсуждение. Проанализирован широкий ассортиментный ряд пеномоющих средств зарубежного и отечественного производств и систематизированы активные фрункциональные группы, вспомогательные и биологически активные вещества. Определены концептуальные различия в подходах к разработке парафармацевтических средств очистительного действия и тенденции использования современных поверхностно-активных веществ «мягкого» действия. Установлено, что создание унифицированных пеномоющих средств в двух интервалах $\mathrm{pH}(3,5-4,5)$ и $(5,0-6,0)$ при нанесении на чувствительные участки кожи и слизистые оболочки обусловливает выбор детергентов, которые бы объединяли достаточные функциональные свойства и дерматологические характеристики. Проведенный анализ показал, что есть необходимость разработки новых подходов к использованию многофункциональных комплексов современных детергентов.

Выводы. Предложен методологический унифицированный подход к созданию пеномоющих средств в двух интервалах $\mathrm{pH}(3,5-4,05)$ и $(5,0-6,0)$, что позволит облегчить разработку средств и их внедрение в отечественное производство.

Ключевые слова: пеномоющие средства очистительного действия; детергенты; рН; шампуни; гели; средства личной гигиены

As the results of the analysis of the modern Ukrainian market for personal care products show, today there is a clear tendency of the increased consumer interest, in particular to detergent-based liquid hygiene products. Shampoos, gels for personal hygiene and shower, liquid soaps, etc., are becoming increasingly popular among all categories of the population. Firstly, this is due to simplicity and ease of use, economy and aesthetics. Secondly, they have many advantages over other personal care products, such as solid soaps. These advantages are the solubility in water of different hardness, high foam formation, cleansing ability, additional actions (antifungal, bactericidal, moisturizing, etc.) [1-3]. Development of the composition of any foaming agent can be considered from the standard approach, namely the choice of detergents of different ionic nature - the choice of excipients - the choice of preservatives. However, when developing these agents the latest tendency is the use of detergents with the "soft" action, which leads to implementation of completely different mechanisms of thickening [4-8]. For example, if detergents of the anionic nature were used as the main or primary detergents, then it was just sufficient to use the electrolytic type of thickening. At present due to the fact that other types of detergents are increasingly used to achieve certain consumer properties (extrusion and ease of dosing, stability for two to three years, etc.), it is necessary to use several types of thickeners at the same time. To meet these requirements it is advisable for technologists to combine the associative and electrolytic thickening mechanisms. Associated thickening occurs due to natural and/or semi-synthetic detergents and / or their combination $[5,6]$.

The aim of the article is to develop a methodological unified approach for creation of foaming agents in two $\mathrm{pH}$ intervals of 3.5-4.5 and 5.0-6.0.

\section{Materials and methods}

The methodological basis of this research is general scientific and applied methods of research, including methods of logical, historical, physicochemical, technolo- gical and analytical analysis. The modern Ukrainian market of foam washing agents and various types of detergents for obtaining satisfactory consumer properties were analyzed [9-12].

\section{Results and discussion}

The study of technological conditions for production of foam washing agents and scientific literary sources showed a number of uncertain issues. The substances used in production of foam washing agents were investigated in the scientific works of such Ukrainian scholars as G. S. Bashura, D. I. Dmitrievsky and foreign scientists (Yu. V. Pletnev), but the issue of creating unified foaming agents in two $\mathrm{pH}$ intervals of 3.5-4.5 and 5.0-6.0 in their works was not analyzed. However, despite the increasing interest of researchers and practitioners to this problem the issue of creating unified detergent-based foaming agents in two $\mathrm{pH}$ intervals of 3.5-4.5 and 5.0-6.0 remains poorly studied. Based on the above the subject is relevant and requires individual research.

After analyzing and summarizing the literary data on theoretical and practical measures for creation of cleansing agents, as well as on the basis of the practical experience, we proposed the methodological approach to development of detergent-based foaming agents in two $\mathrm{pH}$ intervals of 3.5-4.5 and 5.0 -6.0 (Fig.). From a scientific and practical point of view, rather specific foam washing agents differing from each other by the complex of detergents, the $\mathrm{pH}$ value, peculiarities of their application and the physiological significance of the $\mathrm{pH}$ value for these areas were selected.

The methodology for development of any foam washing agents consists of two directions of research (theoretical and experimental), which should be carried out in parallel and complement each other. Taking into account the aforementioned the methodology for creating detergent-based foaming agents in two $\mathrm{pH}$ intervals of 3.5-4.5 and 5.0-6.0 has been developed (Fig.).

In the first place, a number of detergents in the composition of modern foam washing agents and the subs- 


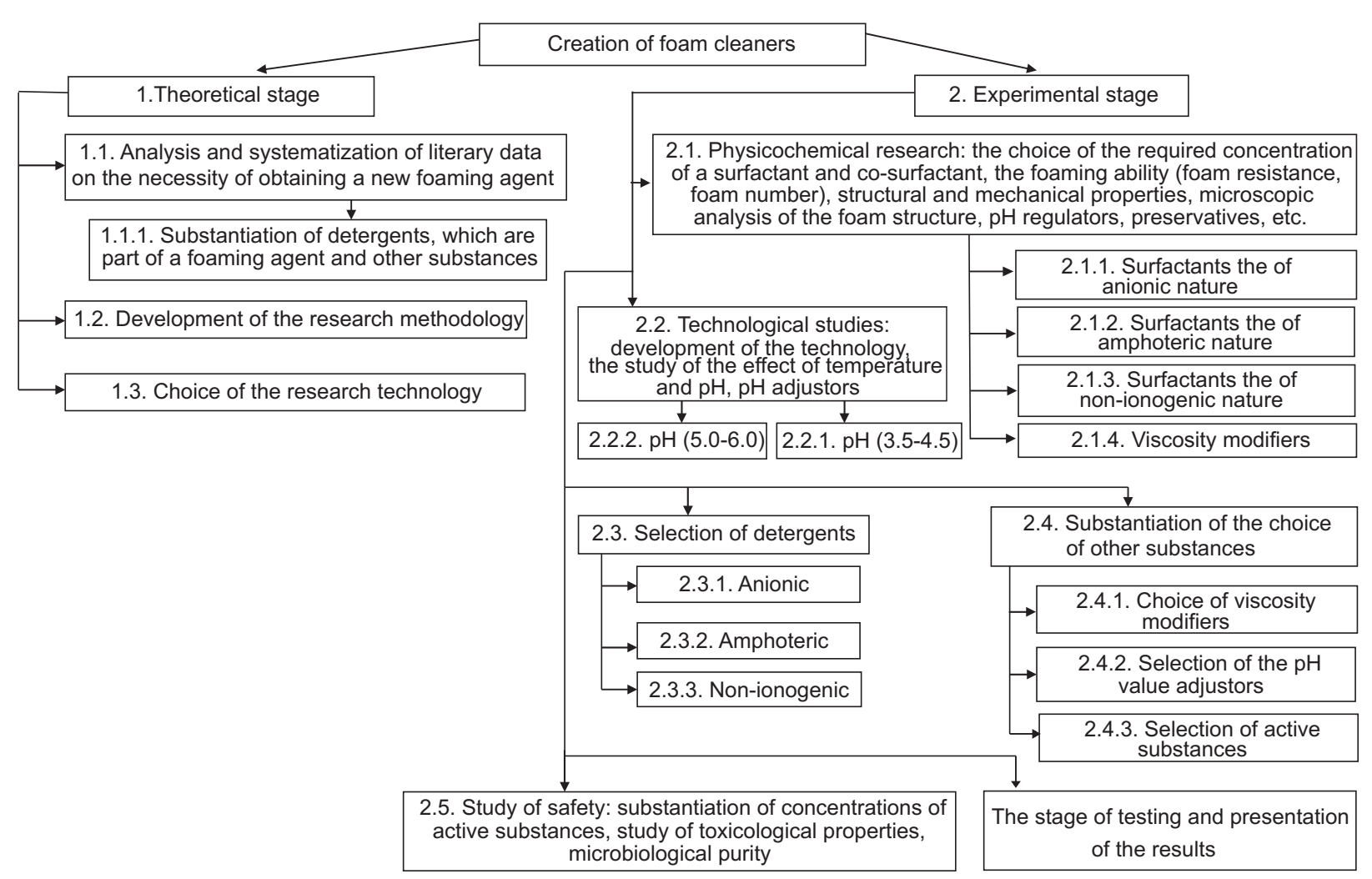

Fig. The methodology for creation of detergent-based foam washing agents developed in pH intervals of (3.5-4.5) and (5.0-6.0)

tances with this effect introduced to the market by manufacturing companies were studied, and their nomenclature was generalized.

Anionic detergents are most commonly used in cleansing agents as primary surfactants. They should combine a high foaming capacity with the ability to the electrolyte thickening.

As secondary surfactants (co-surfactants) amphoteric, nonionic, some anionic substances are commonly used. The use of these surfactants can significantly improve foam characteristics, the system viscosity and provide highly valuable dermatological effects, which are especially important when applied to the mucous membranes, children skin, and the like.

It is exactly at this stage the manufacturer must pay attention to the choice of viscosity modifiers to create a stable system and preservatives.

One of the important stages of research is the choice of viscosity modifiers. This is due to the fact that it is necessary to give preference to the substances and their combinations that have a different mechanism of thickening, which can increase the structural and mechanical properties (in the first place, extrusion of the finished product from the selected type of consumer packaging and stabilization of the system).

An important point is to determine exactly the interval of the $\mathrm{pH}$ value, in which the foaming agents will be able to exhibit their properties. It should be noted that when developing the agents for intimate hygiene it is necessary to select the detergents that will have the cleansing effect exactly at the recommended $\mathrm{pH}$ value - 3.5-4.5. For electrolytic thickening it is necessary to use a standard approach, namely when using anionic detergents an electrolyte with a similar ion should be added. For example, sodium chloride is used when using disodium laureth sulfosuccinate; if amorphous laureth sulfate is used, it is reasonable to introduce ammonium chloride.

It should be also noted that from the technological point of view, it is more appropriate to use solutions of electrolytes which can be optimally introduced in the last place under the strict supervision of the technologist and in small portions since oversaturation of the system with this type of viscosity modifiers can lead to the instantaneous system dilution and turbidity of the gel.

It should be noted that in the experimental studies, first of all, the concentration of detergents affecting the cleansing effect and the presence of side effects is determined, but not the concentration of active substances. Then there is selection of other excipients and active substances, the sequence of their introduction is studied, and the temperature modes are set for each stage.

Using a systematic approach during the scientific and theoretical research it is possible to choose the rational concentration of the selected detergents and active substances.

The study of a number of physicochemical and pharmacological indicators is a combining element of this research with the pharmaceutical development order to determine the optimal shelf-life.

When developing an agent a certain attention is paid to optimization of the manufacturing technology, which includes reduction of the number of stages of the technological process, the use of a reasonable amount of the equipment, determination of critical factors and their parameters, reduction of energy consumption for production. 
Due to the complex of the experimental studies (pharmacotechnological, structural and mechanical, physicochemical, microscopic) the rational composition of the foam washing agent is substantiated, the technology of its production under manufacturing conditions is developed and tested.

\section{CONCLUSIONS}

The methodological approach for development of foam washing agents with different $\mathrm{pH}$ values allows introducing them to the domestic market as safe, competitive products with high cleansing and sufficiently high consumer characteristics.

Based on the above said development or, as we see it, creation of modern foam washing agents is a balanced process with a joint participation of scientists and professionals of pharmaceutical and cosmetic industry.

Conflict of Interests: authors have no conflict of interests to declare.

\section{REFERENCES}

1. Поверхностно-активные вещества и композиции / под ред. М. Ю. Плетнева. - М. : Фирма Клавель, 2002. - 768 с.

2. Surfactants in the management of rhinopathologies / P. L. Rosen, J. N. Palmer, N. A. Cohen et al. // Am. J. Rhinol. Allergy. - 2013. - Vol. 27, Issue 3. - P. 177-180. doi: 10.2500/ajra.2013.27.3873

3. Handbook of Cosmetic Science and Technology / ed. A. O. Barel, M. Paye, H. I. Maibach. - New York : Marcel Dekker, 2001. - 902 p.

4. Zana, R. Gemini Surfactants : Synthesis, Interfacial and Solution-Phase Behavior, and Applicalions / R. Zana, J. Xia. - New York : Marcel Dekker, 2004. - 345 p.

5. Плетнев, М. Ю. Косметико-гигиенические моющие средства / М. Ю. Плетнев. - М. : Химия, 1990. - 456 с.

6. Multifunctional Cocmetic / ed. by R. Shueller, P. Romanowski. - Cambridge : Cambridge University Press, 2003. - 248 p.

7. Research indicators of foaming ability magnesium laurethat from different $\mathrm{pH}$ values / L. S. Petrovskaya, I. I. Baranova, Y. O. Bezpala, C. M. Kovalenko // Asian J. of Pharmac. - 2017. - Vol. 11, Issue 1. - P. 187-190.

8. Петровська, Л. С. Порівняльна характеристика фізико-хімічних показників низки сучасних детергентів при розробці піномийних основ / Л. С. Петровська // Управління, економіка та забезпечення якості в фармації. - 2016. - № 4 (48). - С. 21-24.

9. Сабитов, Р. А. Основы научных исследований : учеб. пособие / Р. А. Сабитов. - Челябинск, 2002. - 138 с.

10. Кузнецов, И. Н. Научные работы : методика подготовки и оформления / И. Н. Кузнецов. - Мн, 1998. - 272 с.

11. Методы исследований и организация экспериментов / под ред. проф. К. П. Власова. - Х. : Гуманитарный центр, $2002 .-256$ с.

12. De Polo, K. F. A short textbook of cosmetology / K. F. De Polo. - Augsburg : Verlag fur chemische Industrie, 1998. - 25 p.

\section{REFERENCES}

1. Pletnev, M. Yu. (2002). Poverkhnostno-aktivnye veshchestva i kompozitcii. Moscow: Firma Klavel, 768.

2. Rosen, P. L., Palmer, J. N., O’Malley, B. W., Cohen, N. A. (2013). Surfactants in the management of rhinopathologies. American Journal of Rhinology \& Allergy, 27 (3), 177-180. doi: 10.2500/ajra.2013.27.3873

3. Barel, A. O., Paye, M., Maibach, H. I. (2001). Handbook of Cosmetic Science and Technology. New York: Marcel Dekker, 902.

4. Zana, R., Xia, J. (2004). Gemini. Surfactants: Synthesis, Interfacial and Solution-Phase Behavior, and Applicalions. New York: Marcel Dekker, 345.

5. Pletnev, M. Yu. (1990). Kosmetiko-gigienicheskie moiushchie sredstva. Moscow: Khimiia, 456.

6. Shueller, R., Romanowski, P. (Eds.). (2003). Multifunctional Cocmetic. Cambridge: Cambridge University Press, 248.

7. Petrovskaia, L. S., Baranova, I. I., Bezpala, Y. O., Kovalenko, C. M. (2017). Research indicators of foaming ability magnesium laurethat from different $\mathrm{pH}$ values. Asian Journal of Pharmaceutics, 11 (1), 187-190.

8. Petrovska, L. S. (2016). Upravlinnia, ekonomika ta zabezpechennia yakosti v farmatsii, 4 (48), 21-24.

9. Sabitov, R. A. (2002). Osnovy naychnykh issledovanii. Cheliabinsk, 138.

10. Kuznetcov, I. N. (1998). Naychnye raboty: metodika podgotovki i oformleniia. Minsk, 272.

11. Vlasov, K. P. (2002). Metody issledovanii i organizatciia eksperimentov. Kharkov: Gumanitarnyi tcentr, 256.

12. De Polo, K. F. (1998). A short textbook of cosmetology. Augsburg: Verlag fur chemische Industrie, 25.

\section{Information about authors:}

Baranova I. I., Doctor of Pharmacy (Dr. habil), professor of the Department of Commodity Science, National University of Pharmacy.

E-mail: innabaranovapharm@ukrnet. ORCID - http:orcid.org/0000-0003-2827-265x

Petrovska L. S., Candidate of Pharmacy (Ph.D), associate professor of the Department of Cosmetology and Aromology, National University of Pharmacy.

E-mail: 1.s.petrovskaya96@gmail.com. ORCID - http:orcid.org/0000-0003-4914-9650

Bezpala Y. O., Candidate of Pharmacy (Ph.D), teaching assistant of the Department of Commodity Science, National University of Pharmacy.

E-mail: yuliyabespalaya5@gmail.com. ORCID - http:orcid.org/0000-0002-0077-8934

Zaika S. V., teaching assistant of the Department of Commodity Science, National University of Pharmacy

Інформація про авторів:

Баранова I. І., д-р фарм. наук, професор, завідувач кафедри товарознавства, Національний фармацевтичний університет.

Баранова I. І., д-р фарм. наук, професор, завідувач кафедри товарознавства, Націо

Петровська Л. С., канд. фарм. наук, доцент кафедри косметології і аромалогіi, Національний фармацевтичний університет.

E-mail: 1.s.petrovskaya96@gmail.com. ORCID - http: orcid.org/0000-0003-4914-9650

Безпала Ю. О., канд. фарм. наук, асистент кафедри товарознавства, Національний фармацевтичний університет. E-mail: уuliyabespalaya5@gmail.com.

ORCID - http: orcid.org/0000-0002-0077-8934

Заїка С. В., асистент кафедри товарознавства, Національний фармацевтичний університет

Информация об авторах:

Баранова И. И., д-р фарм. наук, профессор, заведующая кафедрой товароведения, Национальный фармацевтический университет.

Баранова И. И., д-р фарм. наук, профессор, заведующая кафедрой товароведения,
E-mail: innabaranovapharm@ukr.net. ORCID - http:orcid.org/0000-0003-2827-265x

Петровская Л. С., канд. фарм. наук, доцент кафедры косметологии и аромалогии, Национальный фармацевтический университет.

E-mail: 1.s.petrovskaya96@gmail.com. ORCID - http:orcid.org/0000-0003-4914-9650

Беспалая Ю. А., канд. фарм. наук, ассистент кафедры товароведения, Национальный фармацевтический университет. Е-таil: уuliyabespalaya5@gmail.com.

ORCID - http:orcid.org/0000-0002-0077-8934

Заика С. В., ассистент кафедры товароведения, Национальный фармацевтический университет 